\title{
Validasi Metode Pengujian Biochemical Oxygen Demand (BOD) dalam Air Laut Secara Titrimetri Berdasarkan SNI 6989.72:2009
}

\author{
Validation of Biochemical Oxygen Demand (BOD) of Seawater Testing \\ Methods Using Titrimetry Based on SNI 6989.72:2009
}

\author{
Oktaria Diah Pitalokasari' ${ }^{1}$, Shohibul Fikri ${ }^{2}$ dan Dini Ayudia ${ }^{1}$ \\ 'Puslitbang Kualitas dan Laboratorium Lingkungan (P3KLL)-KLHK, Kawasan PUSPIPTEK Gedung 210, \\ Serpong, Tangerang Selatan, 15310 \\ ${ }^{2}$ Program Studi Kimia Fakultas Sains dan Tehnologi, Universitas Islam Negeri Syarif Hidayatullah Jakarta, \\ Jl. Ir H. Juanda No.95, Tangerang Selatan, 15412 \\ E-mail: oktaria.diahpitalokasari@yahoo.co.id
}

Diterima 3 Februari 2021, direvisi 2 Maret 2021, disetujui tanggal 29 April 2021

\begin{abstract}
ABSTRAK
Validasi Metode Pengujian Biochemical Oxygen Demand (BOD) dalam Air Laut Secara Titrimetri Berdasarkan SNI 6989.72:2009. Metode Standar Nasional Indonesia (SNI) untuk Pengujian BOD di air laut selama ini belum ada. Cara Uji Kebutuhan Oksigen Biokimia atau Biochemical Oxygen Demand (BOD) (SNI 6989.72:2009) hanya berlaku untuk air dan air limbah. Penelitian ini bertujuan untuk memvalidasi metode SNI 6989.72:2009 untuk matrik air laut. Validasi metode pengujian BOD pada air laut ini dilakukan secara titrimetri, berdasarkan penentuan oksigen terlarut sebelum dan sesudah inkubasi pada temperatur $20^{\circ} \mathrm{C}$ selama 5 hari $\left(\mathrm{BOD}_{5}\right)$. Hasil validasi memperlihatkan bahwa jumlah populasi bakteri optimum dalam analisis BOD air laut 19,64 x $10^{6} \mathrm{CFU} / \mathrm{mL}$ atau $4 \mathrm{~mL}$ Polyseed dalam 1 botol winkler $100 \mathrm{~mL}$, dengan konsentrasi $\mathrm{BOD}_{5}$ standar GGA $174,73 \mathrm{mg} / \mathrm{L}$, dan $\% \mathrm{O}_{2} 54,06$, hasil ini sesuai dengan standar APHA No. 5210-2012. Nilai akurasi validasi berada dalam rentang 88-96\%, presisi $\%$ RSD yang diterima, serta hasil pengujian yang linear. Hasil pengujian atau pengukuran menunjukan bahwa $\mathrm{BOD}_{5}$ dengan bakteri isolasi dan Polyseed menunjukkan bahwa terdapat perbedaan berdasarkan uji t, Nilai BOD5 sampel air laut yang digunakan sebesar 12,38 mg/L, melebihi baku mutu BOD ${ }_{5}$ sesuai KEPMENLH No 51 Th. 2004 untuk air laut wisata bahari $(<10 \mathrm{mg} / \mathrm{L})$ namun belum melebihi baku mutu kawasan biota laut $(<20 \mathrm{mg} / \mathrm{L})$.
\end{abstract}

Kata kunci: Air laut, BOD, SNI 6989.72:2009, titrimetri, validasi metode.

\section{ABSTRACT}

Validation Methods of Biochemical Oxygen Demand (BOD) in Sea Water Testing Using Titrimetry Based on SNI 6989.72:2009. There is no Standard Nasional Indonesia (SNI) for BOD testing in determining the seawater quality index in the BOD test there is no Indonesian National Standard (SNI) method, then tritimetry measurement of BOD pollution in seawater carried out by referring to SNI 6989.72: 2009 (BOD testing method for wastewater and surface water). This study aimed to validate the SNI 6989.72: 2009 method on determining the value of the Water Quality Index (WQI) BOD in the seawater matrix. The validation of the BOD test method in seawater was carried out titrimetrically, based on the determination of dissolved oxygen before and after incubation at $20^{\circ} \mathrm{C}$ for 5 days $\left(B O D_{5}\right)$. The results of the validation carried out in this study obtained the optimum number of bacterial populations in the analysis of BOD seawater 19,64 x $106 \mathrm{CFU} / \mathrm{mL}$ or $4 \mathrm{~mL}$ of Polyseed in one $100 \mathrm{~mL}$ Winkler bottle, with a standard $\mathrm{BOD}_{5}$ concentration of GGA 174,73 $\mathrm{mg} / \mathrm{L}$, and $\% \mathrm{O}_{2} 54,06$. These results are in accordance with APHA standard No. 5210-2012. The validation of this method produces accuracy values in the range $88-96 \%$, precision $\% R S D$ received, and linear test results. The test or measurement results show that the $\mathrm{BOD}_{5}$ value with isolated bacteria and Polyseed is different based on the t-test, 
where the test results of sea water samples carried out in the laboratory are $12,38 \mathrm{mg} / \mathrm{L}$, exceeding the $\mathrm{BOD}_{5}$ quality standard according to KEPMENLH No. 51 Th. 2004 for marine tourism seawater $(<10$ $\mathrm{mg} / \mathrm{L})$ but it has not exceeded the quality standard for marine biota areas $(<20 \mathrm{mg} / \mathrm{L})$.

Keywords: seawater, BOD, SNI 6989.72: 2009, titrimetry, methods validation.

\section{Pendahuluan}

Limbah hasil kegiatan yang dialirkan ke perairan dapat mencemari sungai atau laut dan menimbulkan berbagai masalah penyakit bagi manusia dan lingkungan. Salah satu cara yang dapat dilakukan untuk memantau kualitas air adalah dengan mengukur BOD (Biochemical Oxygen Demand). Parameter BOD memberikan informasi mengenai fraksi yang siap terurai dari bahan organik yang mengalir di dalam air (Sara et al., 2018).

BOD adalah jumlah oksigen yang dibutuhkan oleh mikroorganisme aerobik untuk menguraikan hampir semua zat organik yang terlarut maupun yang tersuspensi di dalam air. Nilai BOD dinyatakan dalam miligram oksigen yang dikonsumsi per liter sampel selama 5 hari $\left(\mathrm{BOD}_{5}\right)$ inkubasi pada suhu $20^{\circ} \mathrm{C}$. Nilai BOD sering digunakan sebagai indikator untuk menunjukkan tingkat polusi organik dalam air. Masa inkubasi selama 5 hari $\left(\mathrm{BOD}_{5}\right)$ adalah waktu yang paling umum digunakan karena relatif singkat dan praktis untuk mendeteksi pemecahan biologis bahan organik dalam limbah (Dasgupta \& Yildiz, 2016). BOD $_{5}$ mampu mengurai $70 \%$ zat organik, sehingga nilai tersebut sudah mewakili total zat organik dalam contoh uji (Henze et al., 2008).

Cara lain pengujian BOD dilakukan dengan menggunakan metode winkler. Prinsip dari metode winkler yaitu oksigen di dalam sampel mengoksidasi $\mathrm{MnSO}_{4}$ yang ditambahkan ke dalam larutan pada keadaan alkalis, sehingga terjadi endapan $\mathrm{MnO}_{2}$. Penambahan asam sulfat dan kalium iodida membebaskan iodin yang ekuivalen dengan oksigen terlarut. Iodin yang dibebaskan tersebut kemudian dianalisis dengan metode titrasi iodometri (Hayati, 2016).

Penelitian Hamuna et al., (2018) di perairan Distrik Depapre, Kabupaten Jayapura, Provinsi Papua diperoleh $\mathrm{BOD}_{5}$ $8-13 \mathrm{mg} / \mathrm{L}$ yang berarti perairan Depapre masih dalam keadaan normal, karena standar maksimum $\mathrm{BOD}_{5}$ yang dianjurkan untuk biota air laut dalam keputusan Menteri Negara Lingkungan Hidup No. 51 tahun 2004 adalah $20 \mathrm{mg} / \mathrm{L}$. Penelitian lain yang dilakukan oleh Supriyantini et al., (2017), di wilayah pesisir pantai utara Kota Semarang, menunjukan bahwa kandungan parameter organik di semua lokasi adalah sebagai berikut: $\operatorname{BOD}(3,77-15,13 \mathrm{mg} / \mathrm{L}), \mathrm{COD}(20$ - 140,67 mg/L), TSS $(1.33-13,67 \mathrm{mg} / \mathrm{L})$, TDS $(818,33$ - $2.000 \mathrm{mg} / \mathrm{L})$, dan TOM $(10,73-50 \mathrm{mg} / \mathrm{L})$.

Validasi perlu dilakukan terhadap metode non standar untuk menegaskan dan mengkonfirmasi bahwa metode tersebut sesuai dengan penggunaannya. Validasi metode analisis adalah suatu tindakan penilaian terhadap parameter tertentu, berdasarkan percobaan laboratorium, sangat penting untuk membuktikan bahwa parameter tersebut memenuhi persyaratan untuk penggunaannya, sehingga metode tersebut dikatakan valid. Hasil uji yang valid secara sederhana dapat digambarkan sebagai hasil uji yang mempunyai akurasi (accuracy) dan presisi (precission) yang baik (Harmita, 2012). Penelitian ini bertujuan untuk memvalidasi metode pengujian BOD dalam air laut dengan cara titrimetri berdasarkan SNI 6989.72:2009. 


\section{Metodologi}

Pengujian BOD menggunakan mikroorganisme dipengaruhi oleh kinerja mikroorganisme yang tergantung pada salinitas, temperatur, oksigen, dan $\mathrm{pH}$ (Hayati, 2016). Air laut memiliki perbedaan nutrisi serta kandungan mineral dengan air limbah dan air permukaan serta salinitas atau kadar garam yang tinggi yang menyebabkan kurang maksimalnya kinerja mikroorganisme dalam pengujian BOD. Penelitian ini menambahkan bakteri biakan Polyseed dan bakteri isolasi untuk mengevaluasi perbedaan kinerja kedua bakteri. Jumlah populasi bakteri hasil isolasi dari air laut yang optimum diperoleh dari penambahan jumlah populasi bakteri secara bertahap terhadap nilai BOD larutan standar.

Penelitian ini dilakukan dari bulan September 2019 sampai dengan Februari 2020 di Pusat Penelitian dan Pengembangan Kualitas dan Laboratorium Lingkungan (P3KLL) di Serpong, Kota Tangerang Selatan. Peralatan yang digunakan dalam penelitian ini antara lain spektrofotometer SHIMADZU UV-1601, botol winkler $100 / 102 \mathrm{~mL}$, botol air pengencer $10 \mathrm{~L}$, lemari inkubator, buret, cawan petri, tabung reaksi, jarum ose, bunsen, hotplate, $\mathrm{pH}$ meter HORIBA D55, pipet eppendorf, autoclave, dan peralatan gelas lainnya. Bahan yang digunakan yaitu contoh uji air laut, air suling, Glukosa Asam Glutamat, Polyseed (inter lab), Asam Sulfat $\left(\mathrm{H}_{2} \mathrm{SO}_{4}\right)$, larutan Alkalin Azida, Manganese Sulfat $\left(\mathrm{MnSO}_{4} \cdot 5 \mathrm{H}_{2} \mathrm{O}\right)$, Indikator Kanji, Kalium Iodat $\left(\mathrm{KIO}_{3}\right)$, Natrium Tiosulfat $\left(\mathrm{Na}_{2} \mathrm{~S}_{2} \mathrm{O}_{3} .5 \mathrm{H}_{2} \mathrm{O}\right)$, Natrium Hidroksida $(\mathrm{NaOH})$, larutan $\mathrm{A}$ (Buffer $\mathrm{pH}$ $7,2)$, larutan $\mathrm{B}\left(\mathrm{MgSO}_{4}\right)$, larutan $\mathrm{C}\left(\mathrm{CaCl}_{2}\right)$, larutan $\mathrm{D}\left(\mathrm{FeCl}_{3}\right)$, serbuk air pengencer (air laut buatan), media Nutrient Agar (NA), media Lactose Broth (LB), larutan Phospate Buffer Saline (PBS), Barium Klorida $\left(\mathrm{BaCl}_{2}\right)$.

Pengambilan contoh uji dilakukan di satu titik, yaitu di tepi pantai Marunda. Di sekitar lokasi pengambilan contoh uji terdapat beberapa aktivitas masyarakat seperti pencarian ikan dan kerang laut, serta terdapat aktivitas kapal-kapal industri yang sedang beroperasi. Titik lokasi pengambilan sampel disajikan pada Gambar 1.

Penelitian initerdiri dari beberapa tahap yaitu; (1) Optimasi bakteri menggunakan Polyseed, (2) Pengambilan sampel air laut, (3) Isolasi bakteri air laut, (4) Optimasi

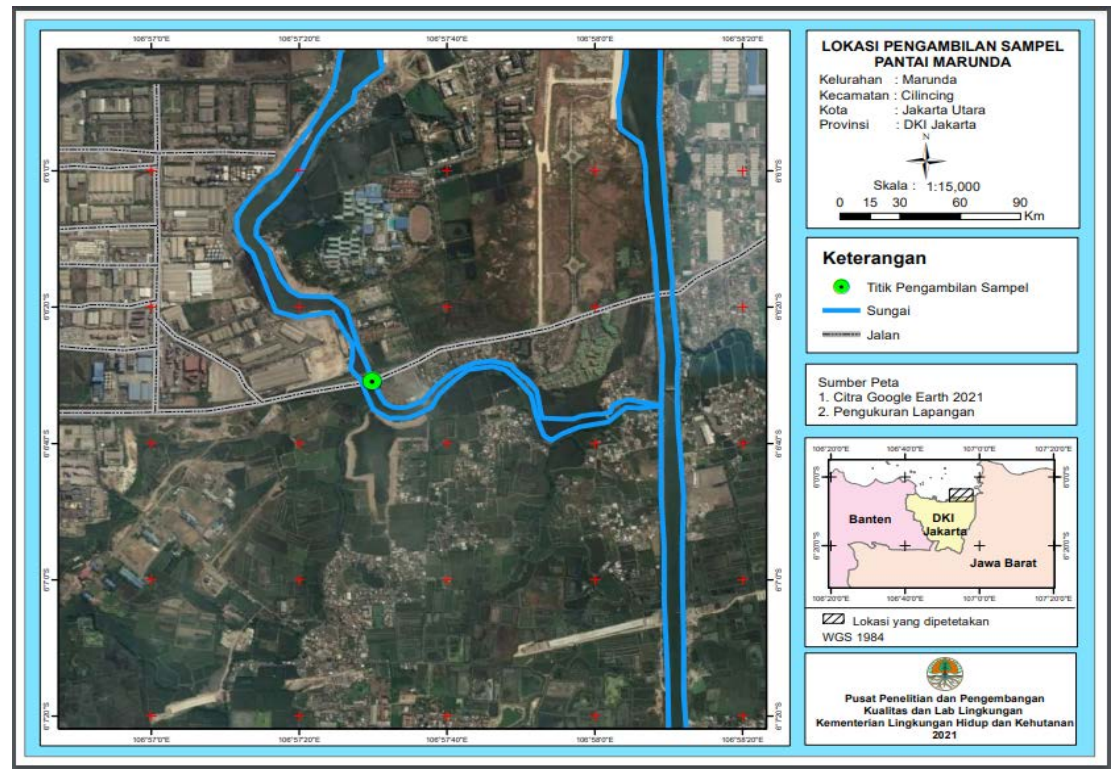

Gambar 1. Titik lokasi pengambilan sampel air laut untuk isolasi bakteri 
bakteri menggunakan bakteri hasil isolasi dan penghitungan kepadatan bakteri, (5) Analisis $\mathrm{BOD}_{5}$ dengan Polyseed dan Bakteri Isolasi, dan (6) Analisis dan validasi data. Tahapan tersebut diuraikan sebagai berikut.

1). Optimasi bakteri menggunakan Polyseed $\mathrm{H}_{2} \mathrm{SO}_{4} \quad 1 \%$ dan $\mathrm{BaCl}_{2} 1 \%$ disiapkan untuk membuat kurva standar McFarland (Sutton, 2011) seperti pada Tabel 1. Absorbansi larutan diukur menggunakan spektrofotometer pada panjang gelombang $600 \mathrm{~nm}$. Pembuatan kurva standar McFarland dilakukan menggunakan bakteri isolasi pada saat optimasi bakteri.

Tabel 1. Petunjuk preparasi standar McFarland

\begin{tabular}{ccc}
\hline $\begin{array}{c}\text { Larutan Standar } \\
(\mathbf{C F U} \mathbf{x}\end{array}$ & \multicolumn{2}{c}{ Volume dalam $\mathbf{~ m L}$} \\
\cline { 2 - 3 } $\left.\mathbf{1 0}^{\mathbf{8}}\right)$ & $\mathbf{B a C l}_{\mathbf{2}} \mathbf{1 \%}$ & $\begin{array}{c}\mathbf{H}_{\mathbf{2}} \mathbf{S O}_{\mathbf{4}} \\
\mathbf{1 \%} \%\end{array}$ \\
\hline 0,5 & 0,5 & 99,5 \\
1 & 1 & 99 \\
2 & 2 & 98 \\
3 & 3 & 97 \\
4 & 4 & 96 \\
5 & 5 & 95 \\
\hline
\end{tabular}

Sumber: John Hopkins University, 2009

\section{2). Pengambilan contoh uji air laut}

Contoh uji berupa air laut untuk isolasi bakteri diambil di Marunda, muara dengan salinitas air lebih dari 2,5\%, pada kedalaman rata-rata 20-50 cm, sebanyak $10 \mathrm{~L}$. Contoh uji tersebut disimpan dalam botol Duran kaca berwarna coklat yang telah disterilkan dalam autoclave pada suhu $121^{\circ} \mathrm{C}$ selama 15 menit. Contoh uji disimpan dalam ruang dingin sebelum dilakukan proses isolasi.

\section{3). Isolasi bakteri air laut}

Perlakuan pertama adalah peremajaan bakteri dengan media lactose broth (LB), media sebanyak $1,3 \mathrm{~g}$ dengan $\mathrm{pH}$ 6,9 $\pm 0,2$ dilarutkan dalam $100 \mathrm{~mL}$ air suling, lalu dipanaskan hingga media tersebut terlarut. Kemudian diambil sebanyak $10 \mathrm{~mL}$ media dan dimasukkan ke dalam tabung reaksi lalu disterilkan dengan autoclave pada suhu $121^{\circ} \mathrm{C}$ selama 15 menit, kemudian didinginkan. Contoh uji air laut diambil sebanyak $1 \mathrm{~mL}$ dimasukkan ke dalam media LB (Laktosa Broth) untuk diinkubasi selama 24 jam pada suhu $35^{\circ} \mathrm{C}$. Hasil inkubasi digores ke dalam media miring NA (Nutrien Agar), lalu diinkubasi kembali selama 24 jam pada suhu $35^{\circ} \mathrm{C}$. Proses tersebut dilanjutkan dengan persiapan bibit bakteri dalam analisis BOD air laut dengan bakteri isolasi.

4). Optimasi bakteri menggunakan bakteri hasil isolasi dan penghitungan kepadatan bakteri

Bibit bakteri hasil isolasi ditambah dengan $\mathrm{NaCl} 1 \%$, lalu sebanyak $1 \mathrm{~mL}$ dimasukkan ke dalam tabung hasil goresan pada media miring NA. Kemudian 10 tabung bibit bakteri diluruhkan dengan ose ke dalam $500 \mathrm{~mL} \mathrm{NaCl} \mathrm{1 \% ,} \mathrm{lalu} \mathrm{diaerasi} \mathrm{selama} 1$ jam untuk analisis. Bakteri yang digunakan untuk isolasi jumlahnya bervariasi, yakni 0,$5 ; 1 ; 2 ; 3$; dan $4 \mathrm{~mL}$ dalam 1 botol winkler blanko dan standar GGA. Bibit bakteri isolasi dilarutkan dalam $\mathrm{NaCl}$ 1\% dan bakteri yang dihasilkan dihitung dengan menggunakan spektrofotometer pada panjang gelombang $600 \mathrm{~nm}$ (sesuai dengan petunjuk metode McFarland).

5). Analisis BOD5 dengan Polyseed (SNI 6989.72:2009) dan Bakteri Isolasi

a. Analisis Blanko dengan Polyseed dan Bakteri Isolasi

Botol winkler 100/102 mL disiapkan sebanyak 4 buah, masing-masing botol diberikan label. Polyseed dimasukkan ke dalam botol winkler dengan variasi jumlah bakteri, kemudian air pengencer dimasukkan ke dalam masing-masing botol secara hatihati, untuk menghindari terbentuknya gelembung udara, kemudian dilakukan pengocokan. Air bebas mineral ditambahkan di sekitar mulut botol winkler yang telah ditutup.

Dua botol disimpan dalam lemari inkubator pada suhu $20^{\circ} \mathrm{C} \pm 1{ }^{\circ} \mathrm{C}$ selama 5 hari, sedangkan 2 botol sisanya ditambahkan $1 \mathrm{~mL} \mathrm{MnSO}_{4}$ dan $1 \mathrm{~mL}$ alkalin dengan ujung 
pipet tepat diatas permukaan larutan. Botol ditutup dengan segera dan dihomogenkan hingga terbentuk gumpalan sempurna. Botol didiamkan hingga gumpalan mengendap secara sempurna kemudian ditambahkan 1 $\mathrm{mL} \mathrm{H}_{2} \mathrm{SO}_{4}$ pekat, ditutup dan dihomogenkan kembali hingga endapan larut sempurna. Sampel dipipet $50 \mathrm{~mL}$ dan dimasukkan ke dalam Erlenmeyer $100 \mathrm{~mL}$, dititrasi dengan $\mathrm{Na}_{2} \mathrm{~S}_{2} \mathrm{O}_{3} .5 \mathrm{H}_{2} \mathrm{O}$ dengan indikator amilum sampai warna biru tepat hilang. Volume $\mathrm{Na}_{2} \mathrm{~S}_{2} \mathrm{O}_{3} .5 \mathrm{H}_{2} \mathrm{O}$ tersebut dikalikan dengan $\mathrm{f}$ Thiosulfat yang digunakan, untuk memperoleh nilai DO. Hal yang sama dilakukan untuk analisis blanko dengan bakteri isolasi (menggunakan air pengencer yang ditambahkan bakteri isolasi).

\section{b. Analisis Standar Glucose Glutamic Acid (GGA) dengan Polyseed dan Bakteri Isolasi}

Analisis $\mathrm{BOD}_{5}$ pada standar GGA dengan persiapan 4 botol winkler 100/102 $\mathrm{mL}$ yang diberikan label. Polyseed dimasukkan ke dalam botol winkler dengan variasi jumlah bakteri, kemudian larutan GGA dipipet $10 \mathrm{~mL}$ ditera dengan larutan pengencer hingga $500 \mathrm{~mL}$. Larutan contoh uji dimasukkan kedalam masing-masing botol secara hati-hati, untuk menghindari terbentuknya gelembung udara, kemudian dilakukan pengocokan. Air bebas mineral ditambahkan di sekitar mulut botol winkler yang telah ditutup.

Dua botol disimpan dalam lemari inkubator pada suhu $20^{\circ} \mathrm{C} \pm 1{ }^{\circ} \mathrm{C}$ selama 5 hari, sedangkan 2 botol sisanya ditambahkan $1 \mathrm{~mL} \mathrm{MnSO}_{4}$ dan $1 \mathrm{~mL}$ alkalin dengan ujung pipet tepat di atas permukaan larutan. Botol ditutup dengan segera dan dihomogenkan hingga terbentuk gumpalan sempurna. Botol didiamkan hingga gumpalan mengendap secara sempurna kemudian ditambahkan 1 $\mathrm{mL} \mathrm{H}_{2} \mathrm{SO}_{4}$ pekat, ditutup dan dihomogenkan kembali hingga endapan larut sempurna. Sampel dipipet $50 \mathrm{~mL}$ dan dimasukkan ke dalam Erlenmeyer $100 \mathrm{~mL}$, dititrasi dengan $\mathrm{Na}_{2} \mathrm{~S}_{2} \mathrm{O}_{3} \cdot 5 \mathrm{H}_{2} \mathrm{O}$ dengan indikator amilum sampai warna biru tepat hilang. Volume $\mathrm{Na}_{2} \mathrm{~S}_{2} \mathrm{O}_{3} .5 \mathrm{H}_{2} \mathrm{O}$ tersebut dikalikan dengan $\mathrm{f}$ Thiosulfat yang digunakan, untuk memperoleh nilai DO. Hal yang sama dilakukan untuk analisis standar GGA dengan bakteri isolasi (menggunakan air pengencer yang ditambahkan bakteri isolasi).

c. Analisis Sampel Air Laut dengan Polyseed dan Bakteri Isolasi

Botol winkler 100/102 mL disiapkan sebanyak 4 buah, masing-masing botol diberikan label. Polyseed dimasukkan ke dalam botol winkler dengan jumlah bakteri sesuai, kemudian sampel air laut tanpa pengenceran dan dengan pengenceran 2 kali dengan air pengencer dimasukkan ke dalam masing-masing botol secara hati-hati, untuk menghindari terbentuknya gelembung udara, kemudian dilakukan pengocokan. Air bebas mineral ditambahkan di sekitar mulut botol winkler yang telah ditutup.

Dua botol disimpan dalam lemari inkubator pada suhu $20^{\circ} \mathrm{C} \pm 1^{\circ} \mathrm{C}$ selama 5 hari, sedangkan 2 botol sisanya ditambahkan $1 \mathrm{~mL} \mathrm{MnSO}_{4}$ dan $1 \mathrm{~mL}$ alkalin dengan ujung pipet tepat diatas permukaan larutan. Botol ditutup dengan segera dan dihomogenkan hingga terbentuk gumpalan sempurna. Botol didiamkan hingga gumpalan mengendap secara sempurna kemudian ditambahkan 1 $\mathrm{mL} \mathrm{H} 2 \mathrm{SO}_{4}$ pekat, ditutup dan dihomogenkan kembali hingga endapan larut sempurna. Sampel dipipet $50 \mathrm{~mL}$ dan dimasukkan ke dalam Erlenmeyer $100 \mathrm{~mL}$, dititrasi dengan $\mathrm{Na}_{2} \mathrm{~S}_{2} \mathrm{O}_{3} .5 \mathrm{H}_{2} \mathrm{O}$ dengan indikator amilum sampai warna biru tepat hilang. Volume $\mathrm{Na}_{2} \mathrm{~S}_{2} \mathrm{O}_{3} .5 \mathrm{H}_{2} \mathrm{O}$ tersebut dikalikan dengan $\mathrm{f}$ Thiosulfat yang digunakan, untuk memperoleh nilai DO. Hal yang sama dilakukan untuk analisis blanko dengan bakteri isolasi (menggunakan air pengencer yang ditambahkan bakteri isolasi). Perlakuan dilakukan pengulangan sebanyak tujuh kali untuk data validasi metode. 
6). Analisis dan validasi data

a. Perhitungan nilai $\mathrm{BOD}_{5}$

$\mathrm{BOD}_{5}=\left(\mathrm{DO}_{0}-\mathrm{DO}_{5}\right) \times \mathrm{fp}$

Keterangan:

$\mathrm{DO}_{0}$ : Nilai Disolved Oxygen contoh uji di hari pertama, $(\mathrm{mg} / \mathrm{L})$

$\mathrm{DO}_{5}$ : Nilai Disolved Oxygen contoh uji di hari kelima, (mg/L)

Fp : Faktor pengenceran.

b. Perhitungan Nilai $\% \mathrm{O}_{2}$

$\% \mathrm{O}_{2}=\left(\mathrm{DO}_{0}-\mathrm{DO}_{5}\right): \mathrm{DO}_{0} \times 100 \ldots$

Keterangan:

$\mathrm{DO}_{0}$ : Nilai Disolved Oxygen contoh uji di hari pertama, $(\mathrm{mg} / \mathrm{L})$

$\mathrm{DO}_{5}$ : Nilai Disolved Oxygen contoh uji di hari kelima, $(\mathrm{mg} / \mathrm{L})$

c. Uji Akurasi dengan Penentuan Persentase Temu Balik (\%Recovery)

Data konsentrasi BOD blanko dan standar GGA yang didapatkan dari replikasi sebanyak tujuh kali dihitung \% recovery menggunakan persamaan sebagai berikut:

$\%$ Recovery $=\frac{\text { Konsentrasi Terukur }}{\text { Konsentrasi Teoritis }} \times 100 \%$

d. Repetabilitas dan Reprodusibilitas $(\%$ RSD)

Data konsentrasi BOD blanko dan standar GGA yang didapatkan dari pengulangan sebanyak tujuh kali dihitung \% RSD (Relative Standard Deviation) yang dibandingkan dengan persamaan Horwitz (Horwitz Value), menggunakan persamaan sebagai berikut:

$\mathrm{SD}=\sqrt{\frac{n \sum_{i=1}^{n} x_{i}^{2}-\left(\sum_{i=1}^{n} x_{1}\right)^{2}}{n(n-1)}}$.

Keterangan:

SD : Simpangan Baku

$\sum x i 2$ : Jumlah kuadrat pengukuran individu

$\sum x i \quad$ Jumlah pengukuran individu

$\mathrm{n} \quad$ : Jumlah ulangan

$\mathrm{RSD}=\frac{\mathrm{SD}}{\bar{x}}$

Keterangan:

RSD : Simpangan Baku Relatif

SD : Simpangan Baku

$\overline{\mathrm{x}} \quad$ : Nilai rata-rata pengukuran
CV Horwits $=2^{1-0,5 \log \mathrm{C}}$

Keterangan :

$\mathrm{C}$ : Konsentrasi rata-rata 7 kali pengulangan

e. Uji-t (Uji Beda)

Pengukuran konsentrasi standar GGA $\mathrm{BOD}_{5}$ menggunakan dua bakteri yang berbeda, yaitu polyseed dan bakteri isolasi yang didapatkan dari pengulangan sebanyak tujuh kali, oleh karena itu dilihat perbedaan hasilnya dengan cara dihitung dengan metode independent sample t-test menggunakan program SPSS.

\section{Hasil dan Pembahasan}

\subsection{Optimasi Bakteri}

Optimasi bakeri dilakukan terhadap bakteri Polyseed sehingga nilai $\mathrm{BOD}_{5}$ yang dihasilkan dapat maksimal serta akurat. Jumlah bakteri dihitung menggunakan metode McFarland (Sutton, 2011).

1). Pembuatan kurva standar perhitungan jumlah bakteri dengan metode McFarland

Metode McFarland adalah perbandingan atau penyetaraan konsentrasi mikroba dengan menggunakan larutan $\mathrm{BaCl}_{2} \quad 1 \%$ dan $\mathrm{H}_{2} \mathrm{SO}_{4} \quad 1 \%$. Standar kekeruhan McFarland dimaksudkan untuk menggantikan perhitungan bakteri satu persatu, dan untuk memperkirakan kepadatan sel bakteri dengan konsentrasi yang diketahui secara spektroskopi (Dalynn Biological, 2014).

MacFarland dengan konsentrasi CFU/ $\mathrm{mL}$ dibuat sebagai konsentrasi estimasi dari Bakteri Gram negatif seperti E.coli. Keuntungan dari penggunaan standar McFarland adalah tidak dibutuhkannya waktu inkubasi yang lama untuk memperoleh jumlah bakteri yang diinginkan karena pembentukan endapan dari campuran larutan $\mathrm{BaCl}_{2} 1 \%$ dan $\mathrm{H}_{2} \mathrm{SO}_{4} 1 \%$ cepat terbentuk. Spektrofotometer yang digunakan yaitu spektrofotometer SHIMADZU UV-1601 dengan pengukuran kekeruhan pada panjang 
gelombang $600 \mathrm{~nm}$ (setara dengan panjang gelombang E.coli) (Sutton, 2011).

Pengukuran jumlah bakteri menggunakan spektrofotometer didasarkan pada kekeruhan seluruh sel bakteri yang hidup dan yang mati terukur sehingga seluruh suspense yang ada dalam larutan kuvet terbaca. Setiap metode kelebihan dan kekurangan yang berbeda, metode spektrofotometer ini tidak membutuhkan waktu yang lama, kepekaan lebih tinggi, lebih mudah digunakan namun hanya dapat menggunakan larutan yang konsentrasinya rendah. Kurva Kalibrasi McFarland dapat dilihat pada Gambar 1. Pembuatan kurva kalibrasi McFarland menghasilkan data yang disajikan pada Tabel 2.

Nilai koefisien korelasi (r) sebesar 0,9998 menunjukkan linearitas karena $\mathrm{r} \geq$ 0,995 . Nilai metode slope (b) merupakan ukuran sensitivitas metode pengujian. Semakin besar nilai $b$ maka metode pengujian mempunyai sensitivitas yang lebih tinggi atau respon instrumen cukup kuat terhadap perubahan konsentrasi. Idealnya intercept (a) adalah nol, namun kenyataannya pada data ditemukan respon instrumen, yang disebabkan oleh gangguan (noise) atau kontaminasi. Hal ini tidak menjadi suatu kesalahan jika diuji linearitas dan akurasinya, nilai tersebut memenuhi batas keberterimaan (Apriyanti et al., 2013).

Tabel 2. Data hasil pembuatan kurva standar McFarland

\begin{tabular}{|c|c|c|c|}
\hline No & $\begin{array}{l}\text { Larutan } \\
\text { Standar }\end{array}$ & $\begin{array}{c}\text { Konsentrasi } \\
\left(\mathrm{CFU} \times 10^{\wedge} 6\right)\end{array}$ & Absorbansi \\
\hline 1 & Blanko & 0 & 0 \\
\hline 2 & Std 0,5 & 150 & 0,119 \\
\hline 3 & Std 1 & 300 & 0,235 \\
\hline 4 & Std 2 & 600 & 0,477 \\
\hline 5 & Std 3 & 900 & 0,714 \\
\hline 6 & Std 4 & 1200 & 0,952 \\
\hline 7 & Std 5 & 1500 & 1,23 \\
\hline \multicolumn{3}{|c|}{ Method Slope } & 0,0008 \\
\hline \multicolumn{3}{|c|}{ Intercept } & $-0,0067$ \\
\hline \multicolumn{3}{|c|}{ Correlation Determination (R) } & 0,9994 \\
\hline \multicolumn{3}{|c|}{ Correlation Coefficien (r) } & 0,9998 \\
\hline \multicolumn{3}{|c|}{ Batas Keberterimaan } & $r \geq 0,995$ \\
\hline
\end{tabular}

2). Optimasi penambahan jumlah bakteri menggunakan polyseed dan bakteri isolasi

Air laut memiliki kadar garam yang tinggi, oleh karena itu dilakukan optimasi bakteri agar didapatkan jumlah bakteri yang optimal pada pengujian $\mathrm{BOD}_{5}$ air laut. Bakteri yang dioptimasi yaitu Polyseed, yang dilakukan dengan pengulangan pengujian $\mathrm{BOD}_{5}$ pada standar GGA yang sesuai dengan aturan standar APHA No.5210-2017.

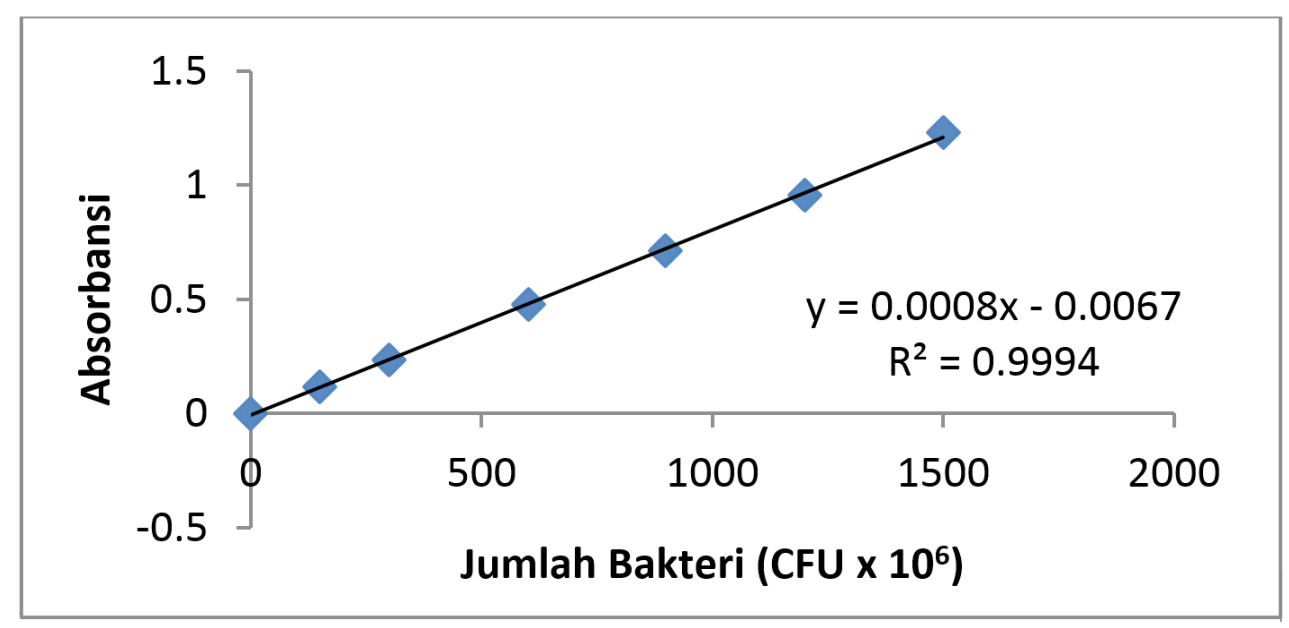

Gambar 2. Kurva kalibrasi McFarland (Dalynn Biological, 2014) 
Tabel 3. Hasil analisis $\mathrm{BOD}_{5}$ standar GGA dengan variasi jumlah bakteri Polyseed

\begin{tabular}{cccccc}
\hline No & $\begin{array}{c}\text { Penambahan } \\
\text { Polyseed }(\mathbf{m L})\end{array}$ & $\begin{array}{c}\text { Jumlah Bakteri } \\
(\mathbf{C F U} / \mathbf{m L}) / \mathbf{1 0 0 m L}\end{array}$ & $\begin{array}{c}\text { Konsentrasi } \\
\text { BOD }_{\mathbf{5}} \text { GGA } \\
(\mathbf{m g} / \mathbf{L})\end{array}$ & $\mathbf{\%} \mathbf{O}_{2}$ & $\begin{array}{c}\text { Standar APHA } \\
\text { No. 5210-2012 }\end{array}$ \\
\hline 1 & 0,5 & $9,3 \times 10^{6}$ & 120,70 & 38,01 & Konsentrasi \\
2 & 1 & $12,13 \times 10^{6}$ & 134,84 & 42,07 & $\mathrm{GGA} 198 \pm 30,5$ \\
3 & 2 & $14,67 \times 10^{6}$ & 144,94 & 44,84 & $\mathrm{mg} / \mathrm{L}$ \\
4 & 3 & $17,13 \times 10^{6}$ & 169,68 & 51,90 & $\mathrm{OO}_{2}=40-70$ \\
5 & 4 & $19,64 \times 10^{6}$ & 174,73 & 54,06 & \\
\hline
\end{tabular}

Jumlah bakteri yang optimum dan sesuai dengan standar APHA No. 52102017 adalah 19,64 x $106 \mathrm{CFU} / \mathrm{mL}$ atau sebanyak $4 \mathrm{~mL}$ Polyseed dalam 1 botol winkler $100 \mathrm{~mL}$ analisis $\mathrm{BOD}_{5}$ air laut, dengan nilai konsentrasi $\mathrm{BOD}_{5}$ standar GGA sebesar 174,73 mg/L dan $\% \mathrm{O}_{2}$ 54,06. Keberadaan bakteri/mikroba merupakan salah satu faktor yang mempengaruhi nilai BOD (Barus, 2004). Air pengencer pada penelitian ini menggunakan air laut simulasi, yaitu air tawar yang ditambahkan garam serta mineral lain sehingga memiliki kandungan unsur-unsur kimia yang sama dengan air laut. Setelah mengetahui jumlah bakteri optimum untuk pengujian $\mathrm{BOD}_{5}$ air laut yang dilakukan menggunakan bakteri Połyseed maka dilakukan validasi metode dengan menggunakan Polyseed dan bakteri hasil isolasi dengan jumlah bakteri (CFU) yang sama atau mendekati sehingga dapat dilihat perbandingan hasil analisis $\mathrm{BOD}_{5}$ menggunakan polyseed dan bakteri isolasi.

\subsection{Validasi Metode BOD $_{5}$ Air Laut dengan Polyseed}

Potyseed merupakan produk yang umum digunakan untuk analisis BOD dalam air limbah dan air permukaan. Polyseed disimpan dalam bentuk kapsul yang jika akan digunakan harus dilarutkan terlebih dahulu dengan air suling dan diaerasi. Dua parameter pengulangan yang dilakukan dalam penelitian ini yaitu penentuan repetabilitas dan reprodusibilitas. Pengulangan pengujian parameter reprodusibilitas Potyseed dilakukan terhadap blanko dan standar GGA sebanyak 7 kali ulang pada hari yang berbeda dengan tujuan untuk mengukur variabilitas hasil pengujian terhadap waktu, kondisi akomodasi, sumberdaya dan lingkungan. Hasil pengujian dapat dilihat pada Tabel 4.

Tabel 4. Reprodusibilitas blanko menggunakan Polyseed

\begin{tabular}{ll}
\hline \multicolumn{1}{c}{ Keterangan } & \multicolumn{1}{c}{ Nilai } \\
\hline Rerata & $0,67 \mathrm{mg} / \mathrm{L}$ \\
Standar Deviasi (SD) & 0,023 \\
\%RSD & 3,38 \\
0,67 Horwitsz Value (PRSDR) & 11,39 \\
\hline Batas Keberterimaan & \\
\%RSD $<0,67$ PRSDR & $3,38<11,39$ \\
\hline
\end{tabular}

Pada Tabel 4, diperoleh kesimpulan bahwa metode yang dilakukan terhadap blanko menggunakan polyseed terbukti valid. Nilai SD blanko adalah 0,023\%, menunjukkan keseragaman pengujian. Nilai \%RSD kecil dan tidak melebihi persamaan Horwitz, yaitu 3,38\% < 11,39\%. Untuk nilai rerata pengujian sebesar $0,67 \mathrm{mg} / \mathrm{L}$, lebih besar dari batas keberterimaan selisih blanko $\mathrm{DO}_{0}$ dan $\mathrm{DO}_{5}$ berdasarkan APHA untuk $\mathrm{BOD}_{5}$ dalam air permukaan $(<0,2 \mathrm{mg} / \mathrm{L})$. Banyaknya faktor pengganggu yaitu Daya Hantar Listrik (DHL) air laut yang tinggi dapat menyebabkan selisih blanko dalam analisis $\mathrm{BOD}_{5}$ menjadi besar. Perairan laut memiliki DHL yang sangat tinggi karena banyak mengandung garam terlarut (Effendy, 2003). Garam - garam terlarut tersebut dapat menyebabkan tingginya nilai blanko dalam pengujian $\mathrm{BOD}_{5}$ dalam air laut. 
Nilai standar deviasi (SD) standar GGA menggunakan Polyseed sebesar 0,96 yang memenuhi syarat keberterimaan standar Horwitz 0,55 $<3,68$. Nilai tersebut menunjukkan keseragaman pengujian satu sampel dengan sampel lainnya (Tabel 5) sehingga metode pengukuran $\mathrm{BOD}_{5}$ untuk standar GGA dengan polyseed dinyatakan valid.

Tabel 5. Reprodusibilitas standar GGA menggunakan Polyseed

\begin{tabular}{lc}
\hline \multicolumn{1}{c}{ Keterangan } & Nilai \\
\hline Rerata & $174,66 \mathrm{mg} / \mathrm{L}$ \\
Standar Deviasi (SD) & 0,96 \\
\%RSD & 0,55 \\
0,67 Horwitsz Value (PRSDR) & 4,93 \\
\%Recovery & 88,2 \\
\%Oksigen & 54,0 \\
Batas Keberterimaan & \\
\%RSD $<0,67$ PRSDR & $0,55<3,68$ \\
\hline
\end{tabular}

\subsection{Validasi Metode BOD $_{5}$ Air Laut dengan Bakteri Isolasi}

Bakteri yang digunakan merupakan hasil isolasi dari sampel air laut di daerah Marunda yang memiliki salinitas $>25$ psu. Bakteri yang dapat tumbuh pada salinitas tinggi disebut bakteri halofilik (Pelczar dan Chan, 1998). Habitat utama mikroorganisme halofilik adalah daerah asin seperti danau air asin, laut, daerah laut dalam, lumpur dan tambak. Untuk melindungi aktivitas metabolism bakteri halofilik pada habitat dengan salinitas tinggi (2-30\%) tersebut dan mencegah hilangnya air dalam sel, maka bakteri halofilik mengakumulasi compatible solute. Compatible solute adalah molekul organik terlarut, sifatnya netral, berat molekulnyakecil dan tidak bercamper dengan hasil metabolism sel. Cara adaptasi extreme halofilik adalah dengan mengakumulasi ion anorganik dalam sitiplasma $\left(\mathrm{K}, \mathrm{Na}^{+}\right.$ dan $\mathrm{Cl}^{-}$) untuk menyeimbangkan tekanan osmotik sel dengan lingkungan. Semetara itu mikriorganisme moderate halofilik mengakumulasi senyawa osmolytes organik tertentu pada sitoplasma yang berfungsi sebagai keseimbangan osmotic tanpa menganggu metabolism sel (Nieto dan Vargas, 2002).

Sampel air laut diinokulasikan ke dalam media Lactose Broth dan digores dalam media Nutrient Agar. Perhitungan jumlah bakteri dilakukan dalam medium LB yang diinkubasi pada suhu $35^{\circ} \mathrm{C}$ selama 24 jam dan didapatkan jumlah bakteri sebesar 1,24 x $109 \mathrm{CFU} / \mathrm{mL}$. Kedua media terebut merupakan medium yang dapat digunakan untuk kultivasi berbagai jenis mikroorganisme dan untuk isolasi serta pengayaan bakteri (Merck Microbiology Manual: 446 dalam Tameswari et al., 2013).

Bakteri halofilik moderat dapat ditemukan dalam ikan dan kerang kerangan seperti Pseudomonas, Moraxella, Flavobacterium, Acinibacter dan species Vibrio. Bakteri halofilik extreme tampak berwarna merah atau merah muda dan berasal dari kelompok bakteri Halobacterium dan Halococcus dan terdapat pada makanan yang telah diawetkan dengan penggaraman (Fardiaz, 1992). Bakteri moderat Halibacillus litoralis ditemukan dalam air asin yang berasal dari Bledug Kuwu (Pangasturi et al., 2002)

Pengujian $\mathrm{BOD}_{5}$ menggunakan bakteri hasil isolasi jumlahnya 19,64 x $106 \mathrm{CFU} / \mathrm{mL}$ dalam 1 botol winkler $100 \mathrm{~mL}$. Pengujian tersebut dilakukan pada blanko dan standar GGA, dengan hasil repeatabilitas blanko ditunjukkan pada Tabel 6 .

Tabel 6. Repetabilitas blanko menggunakan bakteri isolasi

\begin{tabular}{lc}
\hline Keterangan & Nilai \\
\hline Rerata & 0,57 \\
Standar Deviasi (SD) & 0,02 \\
\%RSD & 3,50 \\
0,5 Horwitsz Value (PRSDR) & 8,71 \\
\hline
\end{tabular}


Tabel 6 menunjukkan bahwa metode yang dilakukan terhadap blanko dengan bakteri isolasi adalah valid dengan nilai SD blanko sebesar $0,02 \%$, dan \%RSD yang kecil tidak melebihi persamaan Horwitz, yaitu 3,50\% (<8,71\%). Blanko pengujian dengan menggunakan bakteri biakan mendapatkan rerata pengujian sebesar 0,57 mg/L, yang lebih besar dari standar APHA 0,2 mg/L. Berdasarkan data tersebut terdapat pengganggu dalam analisis menggunakan bakteri biakan. Tingginya Daya Hantar Listrik (DHL) dalam air laut yang dapat menyebabkan tingginya selisih blanko dalam analisis $\mathrm{BOD}_{5}$.

Jika dibandingkan dengan data hasil pengulangan blanko dengan Polyseed (Tabel 4), hasil konsentrasi blanko menggunakan bakteri hasil isolasi (Tabel 6) memberikan hasil yang lebih baik dengan selisih nilai $0,10 \mathrm{mg} / \mathrm{L}$. Polyseed merupakan mikroba campuran buatan yang tidak seluruhnya memiliki kemampuan biokimia yang sama dengan bakteri murninya. Perbedaan kemampuan tersebut menyebabkan selisih pengujian blanko menggunakan Polyseed lebih besar. Hasil pengujian standar GGA menggunakan bakteri isolasi disajikan pada Tabel 7.

Tabel 7. Repeatabilitas standar GGA menggunakan bakteri isolasi

\begin{tabular}{lc}
\hline Keterangan & Nilai \\
\hline Rerata & $189,36 \mathrm{mg} / \mathrm{L}$ \\
Standar Deviasi (SD) & 1,36 \\
\%RSD & 0,72 \\
0,5 Horwitsz Value (PRSDR) & 3,63 \\
\%Recovery & 95,6 \\
\%Oksigen & 54,9 \\
\hline
\end{tabular}

Dari GGA didapatkan rerata pengujian sebesar 189,36\%, yang memenuhi batas keberterimaan yang disyaratkan yaitu 167,5 - 228,5 mg/L. Persen RSD sebesar 0,72\% $(<3,63 \%)$, memenuhi batas keberterimaan sehingga metode pengukuran $\mathrm{BOD}_{5}$ standar GGA menggunakan bakteri isolasi dinyatakan valid dan nilai tersebut lebih baik jika dibandingkan penggunaan Polyseed untuk standar GGA (Tabel 5). Karakteristik bakteri isolasi dari air laut (bakteri halofilik) lebih cocok terhadap kondisi penelitian BOD air laut karena bakteri halofilik merupakan mikroorganisme yang tahan terhadap kadar garam tinggi (Oren, 2006).

Kemampuan hidup bakteri halofilik pada kadar garam tinggi disebabkan kemampuan mengakumulasi zat organik terlarut di dalam sitoplasmanya. Tujuannya adalah untuk mencegah hilangnya cairan dari dalam sel akibat dari tingginya tekanan osmotik di luar sel karena meningkatnya konsentrasi $\mathrm{NaCl}$ (DasSarma, 2012). Data hasil pengujian reprodusibilitas sampel memberikan hasil yang baik dibandingkan dengan persamaan Horwitz Value (Tabel 8).

Tabel 8. Reprodusibilitas sampel menggunakan bakteri isolasi

\begin{tabular}{lc}
\hline Keterangan & Nilai \\
\hline Rerata & $12,38 \mathrm{mg} / \mathrm{L}$ \\
Standar Deviasi (SD) & 0,02 \\
\%RSD & 0,20 \\
0,67 Horwitsz Value (PRSDR) & 7,34 \\
\%Oksigen & 83,9 \\
\hline
\end{tabular}

Pengujian reprodusibilitas pada sampel menggunakan bakteri isolasi menghasilkan nilai standar deviasi sebesar 0,02 dan \%RSD sebesar 0,20. Bila dibandingkan dengan persamaan Horwitz data tersebut diterima karena nilai \%RSD < Horwitz Value yaitu $0,20(<7,34)$. Nilai rata-rata $\mathrm{BOD}_{5}$ sampel yang didapatkan sebesar 12,38 $\mathrm{mg} / \mathrm{L}$ sudah melampaui baku mutu $\mathrm{BOD}_{5}$ dalam KEPMENLH No 51 Th. 2004 tentang baku mutu air laut untuk wisata bahari $(<10$ $\mathrm{mg} / \mathrm{L}$ ) sehingga pantai Marunda tidak cocok untuk dijadikan kawasan wisata. Namun, nilai $\mathrm{BOD}_{5}$ sampel air laut Marunda belum melampaui baku mutu untuk kawasan biota laut $(<20 \mathrm{mg} / \mathrm{L})$ sehingga kualitas air laut Marunda dikategorikan tercemar ringan. 
Tingginya nilai $\mathrm{BOD}_{5}$ pada air laut pantai Marunda Jakarta disebabkan oleh aktivitas masyarakat dalam mencari dan mengolah ikan dan kerang laut, serta terdapat aktivitas kapal yang banyak berlabuh di kawasan tersebut. Jenis limbah cair yang dihasilkan dari proses produksi ikan di pasar ikan tradisional maupun di pasar modern mempunyai bahan organik yang cukup tinggi sehingga mudah membusuk, semakin mudah terjadi pembusukan/dekomposisi, maka nilai $\mathrm{BOD}_{5}$ akan semakin besar (Pamungkas, 2016).

\subsection{Uji Beda ( $t$ - Test)}

$\mathrm{BOD}_{5}$ air laut setelah penambahan Polyseed atau bakteri hasil isolasi menunjukkan perbedaan oksigen yang digunakan untuk mengurai bahan organik, yaitu diperoleh konsentrasi GGA sebesar 174,66 mg/L dan 189,36 mg/L. Metode analisis data yang digunakan adalah metode uji-t tidak berpasangan. Uji t-Independent digunakan untuk mengetahui perbedaan rata-rata antara dua kelompok berbeda berdasarkan suatu variabel dependen (Siregar, 2005). Analisis ini digunakan karena data berbentuk kuantitatif jumlah sampel sebanyak 14 data kuantitatif $(<30)$ dari data pengujian reprodusivitas dan data tersebut diasumsikan berdistribusi normal (Siregar, 2005) (lihat Tabel 5 dan Tabel 7).

Tabel 9. Perbedaan hasil pengujian $\mathrm{BOD}_{5}$ pada standar GGA

\begin{tabular}{lcc}
\hline Keterangan & Polyseed & $\begin{array}{c}\text { Bakteri } \\
\text { Isolasi }\end{array}$ \\
\hline Jumlah Sampel & 7 & 7 \\
Rata -Rata & 174,66 & 189,36 \\
Simpangan Baku (SD) & 0,56 & 0,79 \\
Varians & 0,31 & 0,63 \\
\hline
\end{tabular}

Berdasarkan hasil pengolahan data pada Tabel 9 diketahui bahwa terdapat perbedaan konsentrasi $\mathrm{BOD}_{5}$ pada standar GGA, yaitu dengan Potyseed sebesar 174,66 $\mathrm{mg} / \mathrm{L}$ dan bakteri hasil isolasi sebesar 189,36 $\mathrm{mg} / \mathrm{L}$, setelah itu dilakukan uji beda (t-test) (Tabel 10).

Tabel 10. Hasil uji beda (t-test) konsentrasi $\mathrm{BOD}_{5}$ pada standar GGA menggunakan Polyseed dan bakteri isolasi

\begin{tabular}{lc}
\hline Keterangan & Hasil \\
\hline t-Hitung & $-40,035$ \\
t-Tabel & 2,18 \\
$\alpha 5 \%$ & 0,05 \\
t-Value (nilai signifikansi) & 0,00 \\
\hline
\end{tabular}

Tabel 10 menunjukkan hasil nilai t-hitung berdasarkan 2 varians sebesar $-40,035$ (minus tidak dianggap) dan t-tabel sebesar 2,18. Hasil t-hitung dibandingkan dengan t-tabel dengan tingkat kepercayaan $95 \%$. Hipotesis untuk uji $\mathrm{t}$ adalah $\mathrm{H}_{\mathrm{o}}=\mathrm{X}_{1}=$ $\mathrm{X}_{2}$ (tidak ada perbedaan antara penggunaan Polyseed dengan Bakteri Isolasi), dan Ha: $\mathrm{X}_{1}$ $\neq X_{2}$ (terdapat perbedaan antara penggunaan Polyseed dengan Bakteri Isolasi). Kriteria pengujian adalah terima Ho jika t- hitung lebih kecil dari t-tabel serta t-value lebih besar dari 0,05. Karena nilai t-hitung lebih besar dari t-tabel $(40,035>2,18)$ dan t-value $(0,00<0,005)$ maka hipotesis Ho ditolak, artinya terdapat perbedaan antara penggunaan Polyseed dengan bakteri isolasi. Perbedaan tersebut disebabkan oleh karakteristik bakteri isolasi yang lebih sesuai penggunaannya untuk analisis $\mathrm{BOD}_{5}$ dengan matriks air laut, bakteri isolasi dari air laut lebih memiliki sifat tahan terhadap kondisi kadar $\mathrm{NaCl}$ tinggi.

Data pada pengujian blanko dan standar GGA menunjukkan bahwa bakteri hasil isolasi dapat digunakan dalam analisis $\mathrm{BOD}_{5}$ dengan matriks air laut, bakteri isolasi mampu mendegradasi standar GGA lebih besar dibanding dengan Polyseed yaitu dengan selisih rata-rata sebesar $14,7 \mathrm{mg} / \mathrm{L}$, sehingga dari data hasil rata-rata konsentrasi $\mathrm{BOD}_{5}$ standar GGA tersebut menununjukkan bahwa penggunaan bakteri hasil isolasi lebih baik dibandingkan dengan Polyseed. 


\section{Simpulan}

Hasil analisis metode pengujian BOD5 air laut menggunakan bakteri hasil isolasi dinyatakan valid, memiliki akurasi dan presisi yang baik. Nilai rata-rata akurasi (\%Recovery) untuk standar GGA dengan Polyseed 88,2\%; bakteri isolasi 95,6\%. Nilai presisi (\%RSD) dibandingkan dan tidak melebihi nilai persamaan Horwitz. Data untuk blanko \%RSD 3,50< 8,71; standar GGA \%RSD 0,72<3,63; sampel air laut \%RSD 0,20<7,34. Hasil pengujian menunjukkan terdapat perbedaan antara nilai rata-rata penggunaan Polyseed dan bakteri isolasi dalam pengujian standar GGA $\mathrm{BOD}_{5}$ untuk matriks air laut, yaitu Połyseed sebesar 174,66 mg/L dan bakteri hasil isolasi sebesar 189,36 mg/L. Bakteri isolasi menunjukkan hasil yang lebih baik. Uji beda dengan metode independent sample t-test menggunakan SPSS menunjukkan nilai t-value (nilai signifikansi) sebesar 0,00.

\section{Ucapan Terima Kasih}

Penulis mengucapkan terimakasih kepada semua tim teknis di laboratorium Air dan Limbah Cair Pusat Penelitian dan Pengembangan Kualitas dan Laboratorium Lingkungan (P3KLL), Badan Penelitian dan Inovasi-Kementerian Lingkungan Hidup dan Kehutanan.

\section{Kepengarangan}

Seluruh penulis merupakan dengan anggota yang memberikan kontribusi pada tiap bagian. Oktaria Diah Pitalokasari melakukan penyusunan tulisan, pengolahan data dan verifkasi data, Shohibul Fikri melakukan pengujian, dan Dini Ayudia membantu dalam interpretasi data.

\section{Daftar Pustaka}

Apriyanti, D., Santi, V. I., \& Siregar, Y. D. (2013). Pengkajian metode analisis amonia dalam air dengan metode salicylate test kit.
Ecolab, 7(2), 60-70.

Badan Standardisasi Nasional. (2009). SNI 6989.72:2009: Air dan air limbah bagian 72: Cara uji kebutuhan oksigen biokimia (Biochemical Oxygen Demand/BOD).

Barus, T. A. (2004). Pengantar limnologi studi tentang ekosistem air daratan. Medan: USU Press.

Dalynn Biological. (2014). McFarland Standard. Canada: Dalynn Biological.

Dasgupta, M., \& Yildiz, Y. (2016). Assessment of biochemical oxygen demand as indicator of organic load in wastewaters of Morris County, New Jersey, USA. Journal of Environmental \& Analytical Toxicology, 6(3), 378.

DasSarma, S. \& DasSarma, P. (2012). Halophiles and their enzymes: negativity put to good use. Current Opinion in Microbiology, 25, $120-126$.

Effendy, H. (2003). Telaah kualitas air bagi pengelolaan sumberdaya dan lingkungan perairan. Yogyakarta: Penerbit Kanasius.

Fardiaz ,S. (1992). Mikrobiologi pangan I. Jakarta: Gramedia Pustaka Utama.

Hamuna B., Tanjung R.H.R., Suwito, Maury H.K., Alianto. (2018). Kajian kualitas air laut dan indeks pencemaran berdasarkan parameter fisika-kimia di perairan Distrik Depapre, Jayapura. Jurnal Lingkungan, 16(1): 35-4.

Harmita, H. (2012). Petunjuk pelaksanaan validasi metode dan cara Perhitungannya. Pharmaceutical Sciences and Research (PSR), 1(3), 117-135.

Hayati, M. (2016). Perbandingan kadar oksigen terlarut antara air pdam dengan air sumur. The Journal of Muhammadiyah Medical Laboratory Technologist, 2(2): 8-15.

Henze, M., van Loosdrecht, M. C. M., Ekama, G. A., \& Brdjanovic, D. (2008). Biological wastewater treatment. IWA publishing.

Merck. (2005). MicrobFiology Manual. $12^{\text {th }}$ Edition. Germany: Merck KGaA. 313 \& 443.

Nieto JJ dan Vargas C. 2002. Syintesis of osmoprotectants by modertely halophilic 
bacteria: genetic and applied aspects, In: S.G. Pandalai (ed), Recent Research Development in Microbiology, Research Signpost, Trivandrum. Vol.6: 4003-418 pp.

Oren, A. (2006). Halophilic microorganisms and their environments (Vol. 5). Springer Science \& Business Media.

Pamungkas, M. T. O. A. (2016). Studi pencemaran limbah cair dengan parameter BOD5 dan $\mathrm{pH}$ di pasar ikan tradisional dan pasar modern di Kota Semarang. Jurnal Kesehatan Masyarakat (Undip), 4(2), 166-175.

Pangastuti A.D., Wahjuningrum A., Suwato. (2002). Isolasi, Karakteristik, dan Kloning Gen Penyandi $\grave{\alpha}$-Amilase Bakteri Halofilil Moderat asal Bledug Kuwu. Hayati, 9(1): 10-14
Pelczar, M. J. (2019). Dasar-dasar mikrobiologi. Sara, P. S., Astono, W., \& Hendrawan, D. I. (2018). Kajian kualitas air di sungai ciliwung dengan parameter BOD dan COD. Prosiding Seminar Nasional Cendekiawan, 591-597.

Siregar, S. (2005). Statistik terapan untuk penelitian. Jakarta: PT Gramedia Widiasarana Indonesia.

Supriyantini E., Azizah R.T.N., Putri A.F. (2017). Studi kandungan bahan organik pada beberapa muara sungai di kawsan ekosistem mangrove, di wilayah pesisir pantai utara kota Semarang, Jawa Tengah. Buletin OseonogrfiMartan, 6(1):29-38

Sutton S. (2011). Measurement of microbial cells by optical density. Journal of validation Technology (winter 2011), 46-49. 